\title{
13. IODIDE, BROMIDE, MANGANESE, BORON, AND DISSOLVED ORGANIC CARBON IN INTERSTITIAL WATERS OF ORGANIC CARBON-RICH MARINE SEDIMENTS: OBSERVATIONS IN THE NANKAI ACCRETIONARY PRISM ${ }^{1}$
}

\author{
Chen-Feng You, ${ }^{2}$ Joris M. Gieskes, ${ }^{2}$ Robert F. Chen, ${ }^{2}$ Arthur Spivack, ${ }^{2}$ and Toshitaka Gamo ${ }^{3}$
}

\begin{abstract}
This study of the interstitial water concentration-depth distributions of iodide, bromide, boron, $\delta^{11} \mathrm{~B}$, and dissolved organic carbon, as represented by absorbance at $325 \mathrm{~nm}$ (yellow substance: YS) and laser-induced fluorescence (LIF), is a follow-up of the extensive shipboard program of interstitial water analysis during ODP Leg 131. Most of the components studied are associated with processes involving the diagenesis of organic matter in these sediments.

Three zones of the sediment column are discussed separately because of the different processes involved in causing concentration changes:

1. The upper few hundreds of meters: In this zone, characterized by very high sedimentation rates (>1200 m/m.y.), interstitial waters show very sharp increases in alkalinity, ammonia, iodide, bromide, YS, and LIF, mainly as a result of the diagenesis of organic carbon;

2. Whereas below $200 \mathrm{mbsf}$ concentration gradients all show a decreasing trend, the zone at $\sim 365 \mathrm{mbsf}$ is characterized by concentration reversals, mainly due to the recent emplacement of deeper sediments above this depth as a result of thrust-faulting;

3. The décollement zone ( $945-964 \mathrm{mbsf}$ ) is characterized by concentration anomalies in various constituents (bromide, boron, $\delta^{11} \mathrm{~B}$, manganese, LIF). These data are interpreted as resulting from an advective input of fluids along the zone of décollement as recent as $\sim 200 \mathrm{ka}$. Possibly periodic inputs of anomalous fluids still seem to occur along this décollement zone.
\end{abstract}

\section{INTRODUCTION}

Recent studies of accretionary prisms have served to delineate the mode of expulsion of fluids from the sediments as a result of compaction and shortening (Bray and Karig, 1985; Cloos, 1984; Mascle et al., 1988; Moore et al., 1988). Geochemical studies, both of fluid phases and of solid diagenetic phases, have helped to describe the origin of these fluids as well as the nature of the fluid movement (Boulegue et al., 1987; Han and Suess, 1989; Gieskes et al., 1990a, b; Vrolijk et al., 1990, 1991).

Often fluid expulsion occurs from sediments that have relatively high organic carbon contents, thus leading to pore fluid compositions strongly influenced by the decomposition of this organic carbon, either as a result of bacterial activity or as a result of thermal stresses. Typical examples of such fluids are those sampled in the Japan Trench and the Nankai Trough off Japan (Boulegue et al., 1987), off the coast of Oregon (Han and Suess, 1989), and in the Barbados accretionary prism south of Barbados (LePichon et al., 1990). Indeed Boulegue et al. (1987) and Han and Suess (1989) described active venting of fluids out of sediments along fault zones or through carbonate cemented chimneys (Kulm et al., 1986). Though these venting processes are spectacular in nature, the information as to the depth from where these fluids originate is rather sparse, especially in the absence of deeper cores. For this purpose the drilling of holes to as great a depth as possible, preferably near the toes of accretionary wedges, can serve as a guide to the nature of the overall fluid expulsion process. This was demonstrated from the series of drill holes along the northern Barbados accretionary prism transect during DSDPLeg 78A and ODP Leg 110 (Moore et al., 1988; Vrolijk et al., 1991). The second ODP leg that was successful in the penetration of the décollement was Leg

'Hill, I.A., Taira, A., Firth, J.V., et al., 1993. Proc. ODP, Sci. Results, 131: College Station, TX (Ocean Drilling Program).

${ }^{2}$ Scripps Institution of Oceanography, La Jolla, CA 92093-0215, U.S.A.

${ }^{3}$ Ocean Research Institute, University of Tokyo, Japan.
131 , during which one site, Site 808 , was drilled to basement and penetrated the décollement at an approximate depth of $945-964$ mbsf.

In Site 808 a large number of samples of interstitial fluids were gathered, notwithstanding the very low porosities of the sediment. The complete set of shipboard analyses of the inorganic geochemistry of the interstitial waters has been published by Taira, Hill, Firth, et al. (1991), and, where appropriate, use will be made of this data set. Here we report on the data obtained in our home laboratory on the contents of iodide, bromide, boron, $\delta^{11} \mathrm{~B}$, manganese, and dissolved organic carbon as represented by "yellow substance" absorbance (YS) and laser-induced fluorescence (LIF). These components, especially iodide, bromide, YS, and LIF, are representative of the effects of organic carbon diagenesis in these sediments.

\section{METHODS}

In this section we provide a brief description of the methods utilized in this study. The methods for iodide, bromide, and boron are presently part of the ODP shipboard program for chemical analysis (Gieskes, Gamo, and Brumsack, 1991).

Mn: Flameless atomic absorption spectrometry.

YS: This method is based on the measurement of the light absorbance at $325 \mathrm{~nm}$ using a normal wavelength spectrophotometer (see also Brumsack and Gieskes, 1983). The data are expressed in absorbance units for a 1-cm path-length. We chose this wavelength, rather than $280 \mathrm{~nm}$ (Krom and Sholkovitz, 1977), because of the strong absorbance of the samples under study here. Spectral analysis has shown that the spectrum of YS shows no significant peaks from 350 to $200 \mathrm{~nm}$, similar to the observations of Krom and Sholkovitz (1977). These authors showed a correlation between the absorbance and the concentration of dissolved organic carbon, an observation confirmed by us on the basis of measurements on interstitial waters from Hole 475 in the Gulf of California (Michaelis et al., 1982) and on samples from Site 808 (Chen, 1992). We realize that the composition of organic carbon may change with depth, but we consider the distribution of YS to be, to a first approximation, a measure of dissolved organic carbon. 
LIF: This methodology has recently been described by Chen and Bada (1990). Basically, fluorescence is also sensitive to dissolved organic compounds, but is more specific than absorbance, detecting only compounds containing aromatic or conjugated double bond moities. In addition, we have separated some of the samples by means of reversed-phase high-performance liquid chromatography (RPHPLC with LIF detection). Although these fractions have not yet been characterized by any other means than their retention times on a reversed phase column, we deem this information important to gain insight into the compositional changes of dissolved organic matter (DOM) and as an initiation of interest in analyses of DOM in rapidly accumulating, organic carbon-rich sediments.

Boron isotopes: $\delta^{11} \mathrm{~B}$ was determined by negative ion thermal ionization mass spectrometry (Spivack and Edmond, 1987), with a precision of $\pm 1.4 \%$ ( $95 \%$ confidence level).

\section{SITE DESCRIPTION}

For the purpose of this paper we refer to Figure 1, which presents some of the crucial information on this site. The upper $618 \mathrm{~m}$ of sediment consist of rapidly accumulated trench wedge turbidites, with an average sedimentation rate of about $1350 \mathrm{~m} / \mathrm{m}$.y. Especially the upper $120 \mathrm{~m}$ consist of a lower slope apron (to $20.5 \mathrm{mbsf}$ ) and a series of thick-bedded sandy turbidites. Below this, units IIb and IIc consist of thinly bedded sand and silt turbidites with increasing volcanic contents to a depth of about 557 mbsf. A major thrust occurs at $365 \mathrm{mbsf}$ in Hole $808 \mathrm{C}$. A transition from trench to basin sediments characterizes unit III to $618 \mathrm{mbsf}$, below which unit IVa constitutes Upper Shikoku Basin ash/tuff and hemipelagic muds to $824 \mathrm{mbsf}$. From below this depth to 1243 mbsf the sediments consist of Lower Shikoku Basin hemipelagic muds, characterized by only little ash, but with the décollement zone between 945 and 964 mbsf. Finally a thick layer of silicic volcaniclastic deposits covers basaltic basement at 1289 mbsf.

Organic carbon contents of the sediments are presented in Figure 2. It is apparent that the organic carbon contents are much higher in the rapidly deposited section than in the Shikoku Basin deposits. Nonetheless, even in the upper rapidly deposited section, organic carbon contents never exceed 1\%. Another important feature of the organic geochemical data is a pattern of anomalously high hydrocarbon maturity (Ulrich Berner, pers. comm., 1991; Berner and Faber, this volume). Thermogenic hydrocarbons, represented by pentanes, butanes, and propanes, occur between 650 and 800 mbsf and from 1060 to 1280 mbsf (Berner and Faber, this volume), suggesting formation at temperatures higher than presently prevailing as inferred from temperature measurements in the upper section. Estimated temperatures at the base of the hole are about $120^{\circ} \mathrm{C}$, and at $650 \mathrm{mbsf}$ about $65^{\circ} \mathrm{C}$.

\section{RESULTS}

The results for iodide, bromide, boron, $\delta^{11} \mathrm{~B}$, manganese, $\mathrm{YS}$, and LIF are presented in Table 1. Other data on the pore water compositions relevant to this paper can be found in the preliminary reports of Leg 131 (Taira, Hill, Firth, et al., 1991). Data for alkalinity, sulfate, ammonium, manganese, YS, LIF, chloride, iodide, and bromide are presented in Figure 3. Boron and $\delta^{11} \mathrm{~B}$ data are presented in Figure 4.

It is evident that the decomposition of organic carbon has led to a large increase in alkalinity and ammonium in the upper $200 \mathrm{mbsf}$, a phenomenon typical in rapidly deposited sediments, rich in organic carbon (Gieskes, 1983; Harrison et al., 1982; Hesse et al., 1985; Kastner et al., 1990). Sulfate concentrations decrease to zero in the upper $10 \mathrm{~m}$ of the sediment column. Below this the generation of methane dominates the biogenic decomposition of organic matter. We believe that the slightly higher sulfate concentration around $\sim 380$ mbsf result from seawater contamination of these samples, from which very low amounts of pore water were recovered (Taira, Hill,
Firth, et al., 1991). Below a depth of 820 mbsf, however, a small but distinct increase of dissolved sulfate occurs. Similar increases in dissolved sulfate were observed in the deeper sections of Site 297 of the Shikoku Basin (White, 1975). Chloride concentrations show a rapid increase of about $5 \%$ in the upper, rapidly deposited section, to reach a maximum at the base of this section. Below $620 \mathrm{mbsf}$, a gradual decrease in chloride is observed to well below the zone of décollement, followed by a sharp increase toward the zone of volcanic turbidites at the base of the section. Elsewhere (Gieskes et al., this volume; Kastner et al., this volume) the chloride profile will be discussed in greater detail, but the decreases in the deeper parts of the hole are potentially related not only to dehydration of clays in situ, but also to advection of fluids along the décollement or in the deeper section, at least in an intermittent fashion.

The concentration depth profiles of iodide and bromide (Fig. 3) show some scatter, mostly as a result of the small size of the samples used for the analysis of these components. The latter was necessitated by the desire to analyze the pore water samples for as many components as possible. The trend in the iodide data, however, does parallel the trend in the bromide data reasonably well, especially in the upper $800 \mathrm{~m}$ of the profile.

Concentration-depth profiles of boron and the depth profile of $\delta^{11} \mathrm{~B}$ are presented in Figure 4. After an initial maximum in the upper, rapidly deposited sediment section, a rapid drop occurs in boron to almost constant values to below $\sim 400$ mbsf. Below this a gradual increase in boron occurs with a maximum of about $2.5 \mathrm{mM}$ centering around the zone of décollement. A rapid drop in $\delta^{11} \mathrm{~B}$ accompanies this increase in boron and is most likely due to the release of adsorbed boron or fixed boron further in the prism.

Manganese concentrations (Fig. 3) are low throughout the upper $400 \mathrm{mbsf}$, but maxima occur at about $600 \mathrm{mbsf}$ and in the vicinity of the décollement.

Measurement of YS, though not necessarily a direct measure of dissolved organic carbon, should be representative of the major portion of dissolved organic carbon produced during the decomposition of organic matter (Krom and Sholkovitz, 1977). The data are presented in Figure 3. A sharp increase in YS is observed in the upper sediment section, which is also characterized by a sharp maximum in alkalinity (Fig. 3). LIF of organic matter also increases at shallow depth, almost in parallel with YS concentrations. However, near the décollement a maximum in LIF occurs, which is not reflected in a significant increase in the YS absorbance. Data on HPLC separations are presented in Figure 5, in which we have plotted peak area vs. depth for several retention times. The retention times of 5.3 and $0.9 \mathrm{~min}$ are specific for compounds around the zone of décollement.

\section{DISCUSSION}

Because of the complexity of the sedimentary column of Site 808, it will be appropriate to discuss the concentration-depth profiles in terms of processes that may be of the greatest importance in the various sections. For this purpose we will consider:

1. The depth range $0-300 \mathrm{mbsf}$, i.e., the zone characterized by rapid deposition and the occurrence of large-scale diagenesis of organic matter.

2. The range from 300-625 mbsf, i.e., the zone of high rates of sedimentation, but mainly characterized by the occurrence of a recent thrust fault, centered around 365 mbsf.

3. The range from $625 \mathrm{mbsf}$ to the bottom of Hole $808 \mathrm{C}$, with the principal feature being the occurrence of the zone of décollement between 945 and 964 mbsf.

\section{Upper Sediment Section}

Typically, large increases in alkalinity, ammonium, iodide, bromide, boron, YS, and LIF characterize especially the upper $100 \mathrm{~m}$ of 

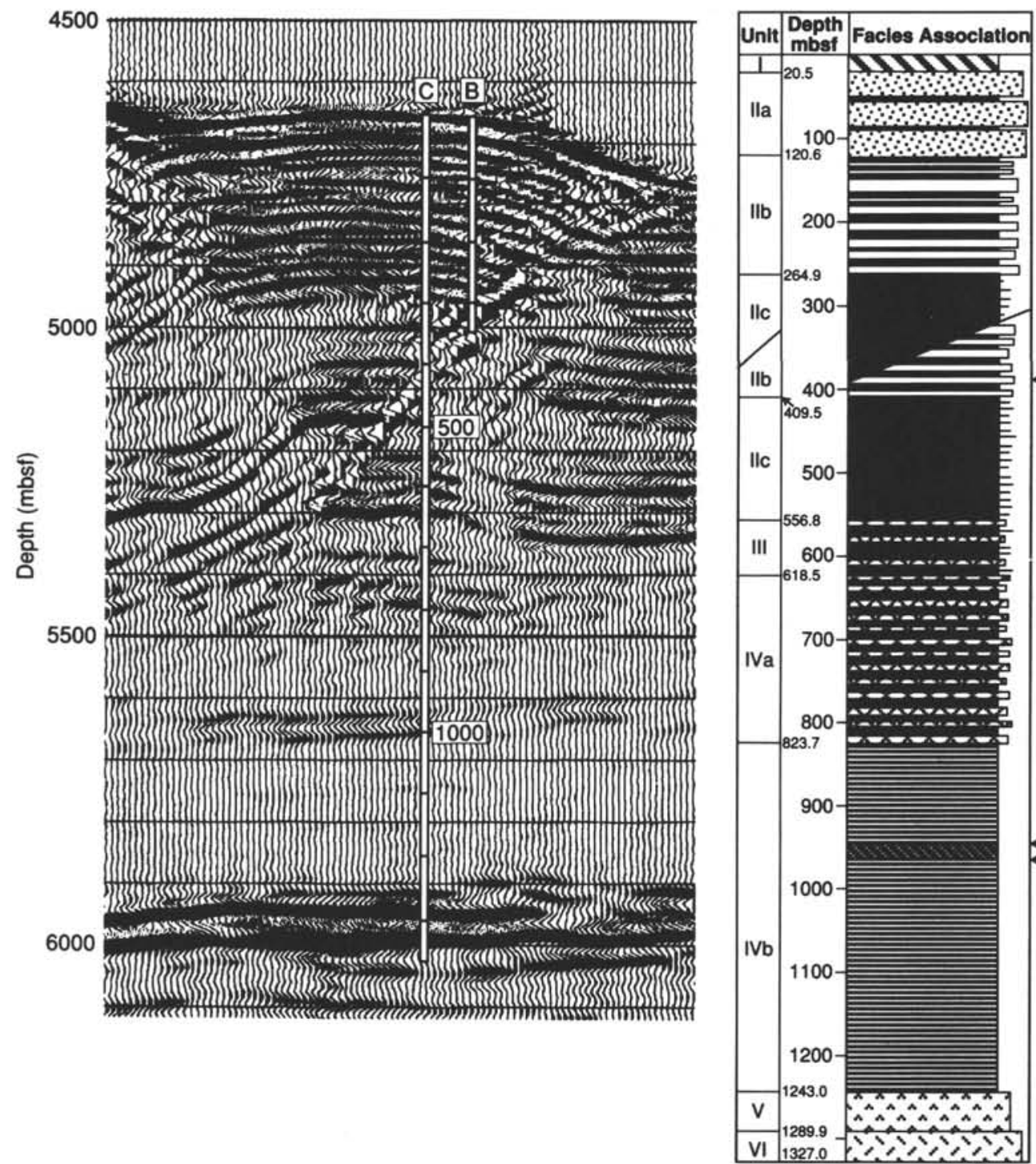

Lower slope apron

(hemipelagic mud, thin turbidites, slides)

Upper axial trench wedge

(thick-bedded sand turbidites)

Lower axial trench wedge

(thin-bedded sand and silt turbidites)

\section{Frontal thrust zone}

between 357-395 mbsf in Hole 808C

Outer marginal trench wedge

(silt turbidites and hemipelagic mud)

Trench-to-basin transition

Upper Shlkoku Basin

(ash/tuff and hemipelagic mud)

\section{-DÉCOLLEMENT ZONE \\ -945-964 mbsf}

Lower Shlkoku Basin
(hemipelagic mud)
Acidic volcaniclastic deposits
Basaltic basement

Figure 1. General seismic and lithostratigraphic information on Site 808. Note thrust fault centered around 365 mbsf; décollement at $945-965$ mbsf, as well as rapid rate of sedimentation of the upper $620 \mathrm{~m}$ of trench-fill deposits $(\sim 1280 \mathrm{~m} / \mathrm{m} . \mathrm{y}$.), from Taira, Hill, Firth, et al. (1991).

the sediment column (Figs. 3 and 4 ). All these components are directly related to the diagenesis of organic carbon in these rapidly deposited sediments. Sulfate is depleted below $\sim 8 \mathrm{mbsf}$, and methane production becomes increasingly important at greater depths (Berner and Faber, this volume). Typically ammonium generation occurs in association with the latter process, leading to an ammonium maximum at $\sim 150$ mbsf, much deeper than the extreme in alkalinity, iodide, bromide, and boron.

Increases in iodide and bromide in pore waters of DSDP sites have been observed by us (Wang et al., 1988) in the organic carbon-rich sediments in the Gulf of California (DSDP Leg 64) and in the area off Guatemala (DSDP Leg 67). Similar observations have been made in the pore waters of the sediments drilled during ODP Leg 112 (Jon Martin, pers. comm., 1991). The ratio of concentration increases in iodide and bromide is $\sim 0.067$ (Fig. 6), only slightly higher than the ratio observed for average marine organic carbon $(\sim 0.062$; Jon Martin, pers. comm., 1991). The scatter in the data is largely due to small sample sizes available for the analysis of iodide. Thus it appears that in the area of Site 808 , little or no enrichment in iodine in the detrital organic matter occurs, contrary to what is often observed in sediments that are deposited at relatively low accumulation rates in waters characterized by fairly high dissolved oxygen concentrations. We speculate that such a lack of iodine enrichment is due to the very high sedimentation rate and the consequently reducing conditions in the surface sediments (Kennedy and Elderfield, 1987a, b). Variation in iodide and bromide at greater depths will be discussed below.

Recent observations in our laboratory on the boron concentrations of interstitial waters obtained from DSDP sites, characterized by sediments rich in organic carbon, have shown relatively large increases in dissolved boron. Similar observations have been made by Brumsack et al. (H.J. Brumsack, pers. comm., 1991) in the interstitial waters recovered from sediments cored during Leg 128 of ODP in the Japan Sea. In the upper $200 \mathrm{~m}$ of Site 808 , this increase in boron correlates well with the sharp increases in alkalinity and YS (Figs. 3 and 4). A decrease in $\delta^{11} \mathrm{~B}$ is associated with this signal. We suggest that the boron maximum is mainly the result of the release of adsorbed $\mathrm{B}$ in this zone of intense organic carbon diagenesis and may well be the result of chemisorption of boron onto the dissolved humic acids (a maximum of about $10 \mathrm{mM}$ of organic carbon is observed in these sediments; Chen, 1992).

YS and LIF values are expected to be high in the upper 100$200 \mathrm{mbsf}$, resulting from diagenesis of organic carbon in these sedi- 

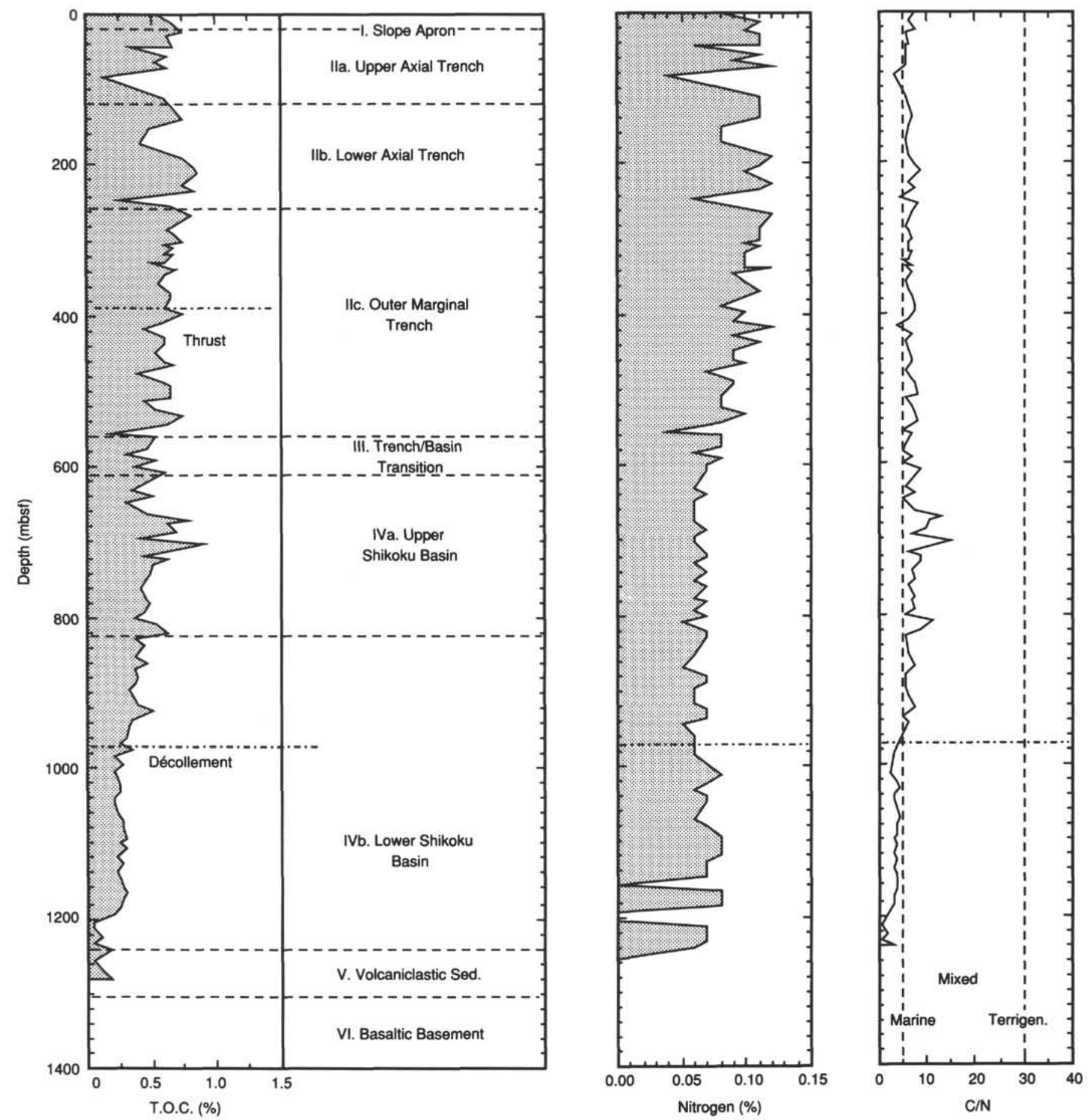

Figure 2. Distribution of organic matter with depth, Site 808. From Taira, Hill, Firth, et al. (1991).

ments rich in organic carbon (also Krom and Sholkovitz, 1977; Brumsack and Gieskes, 1983). Similar observations have also been made by us on pore fluids recovered in the Guaymas Basin during DSDP Leg 64 and those recovered during DSDP Leg 67 off Guatemala. A plot of YS vs. LIF (Fig. 7) shows a reasonable correlation in the upper part of the sediment column, indicating a predominance of aromatic hydrocarbons in the dissolved organic carbon pool (Chen, 1992).

Concentrations of manganese are extremely low in the upper $400 \mathrm{mbsf}$, but a source of manganese appears to be located at the boundary zone between the trench fill turbidites and the Shikoku Basin deposits (Figs. 1 and 3). Typical MnO contents of the solids in the upper $400 \mathrm{msbf}$ are well below $0.1 \%$, with somewhat higher contents in the depth horizon of 600-700 mbsf (Underwood et al., this volume). Any manganese that could be mobilized from possible manganese oxide phases, however, would be removed rapidly in the form of carbonate.

\section{Influence of the Thrust Fault (350-390 Mbsf)}

Below a depth of $\sim 300 \mathrm{mbsf}$ in Hole $808 \mathrm{C}$ reversals occur in many of the interstitial water profiles (e.g., ammonium, iodide, bromide, YS, and LIF in Fig. 3). These reversals were also noted in several of 
Table 1. I, Br, B, $\delta^{11} \mathrm{~B}, \mathrm{Mn}, \mathrm{YS}$, and LIF in pore waters of Site 808.

\begin{tabular}{|c|c|c|c|c|c|c|c|c|}
\hline $\begin{array}{l}\text { Core, section, } \\
\text { interval }(\mathrm{cm})\end{array}$ & $\begin{array}{l}\text { Depth } \\
\text { (mbsf) }\end{array}$ & $\begin{array}{c}\mathrm{I} \\
(\mu \mathrm{M})\end{array}$ & $\begin{array}{c}\mathrm{Br} \\
(\mu \mathrm{M})\end{array}$ & $\underset{(\mathrm{mM})}{\mathrm{B}}$ & $\begin{array}{l}\delta^{11} \mathrm{~B} \\
(\%)\end{array}$ & $\begin{array}{c}\mathrm{Mn} \\
(\mu \mathrm{m})\end{array}$ & $\begin{array}{c}\text { YS } \\
(\text { abs. })^{a}\end{array}$ & $\begin{array}{l}\text { LIF } \\
\text { (flu) }\end{array}$ \\
\hline \multicolumn{9}{|l|}{ 131-808A- } \\
\hline $1 \mathrm{H}-3,0-10$ & 3 & 2 & 991 & 0.64 & 35 & & 0.342 & 17010 \\
\hline $1 \mathrm{H}-4,140-150$ & 6 & 4 & 1054 & 0.78 & & 0.5 & 0.647 & 39790 \\
\hline $2 \mathrm{H}-3,0-10$ & 9.3 & 36 & 1291 & 1.00 & & & 0.839 & \\
\hline $2 \mathrm{H}-5,140-150$ & 13.8 & & & & & & 0.831 & \\
\hline $3 \mathrm{H}-3,0-10$ & 18.8 & 36 & 1398 & & & & 0.799 & \\
\hline $3 \mathrm{H}-5,140-150$ & 23.3 & 38 & 1377 & & & 4.5 & 0.745 & \\
\hline $4 \mathrm{H}-10,135-150$ & 26.8 & 33 & 1507 & 1.05 & & & 0.731 & \\
\hline $5 \mathrm{H}-6,120-135$ & 43.6 & 41 & 1469 & 1.00 & & & 0.666 & 45600 \\
\hline $6 \mathrm{H}-1,0-10$ & 44.3 & 40 & 1383 & & & 1.2 & 0.668 & \\
\hline $7 \mathrm{H}-4,135-150$ & 59.7 & 34 & 1522 & 0.96 & & & 0.641 & 41190 \\
\hline $8 \mathrm{H}-1,135-150$ & 64.7 & 41 & 1468 & 0.99 & & 3 & 0.642 & 43000 \\
\hline $9 \mathrm{H}-3,140-150$ & 72.8 & 33 & 1473 & 1.02 & & & 0.599 & 44410 \\
\hline $10 \mathrm{H}-3,0-15$ & 80.8 & 37 & 1473 & 1.04 & & & & 40180 \\
\hline $13 \mathrm{H}-2,122-137$ & 109 & 35 & 1438 & 0.94 & 37 & & & \\
\hline \multicolumn{9}{|l|}{$131-808 \mathrm{~B}-$} \\
\hline $5 X-1,88-103$ & 151 & 31 & 1413 & & & 4.6 & 0.391 & 21640 \\
\hline $7 X-1,130-145$ & 170 & 39 & 1404 & 0.55 & & & 0.317 & \\
\hline $10 X-4,130-150$ & 203 & 35 & 1321 & 0.61 & 44 & & 0.261 & \\
\hline $11 X-2,125-145$ & 209.7 & 25 & 1294 & & & 5.2 & 0.239 & 19160 \\
\hline $13 X-1,125-145$ & 227 & 27 & 1301 & & & & 0.232 & \\
\hline $17 X-2,130-145$ & 266.5 & 27 & 1300 & 0.45 & & & 0.226 & \\
\hline $19 X-1,135-150$ & 284 & 25 & 1244 & 0.42 & & 3.5 & 0.251 & \\
\hline $22 X-1,140-150$ & 308.5 & 43 & 1314 & 0.38 & & & 0.196 & \\
\hline $24 X-2,70-85$ & 328 & 37 & 1305 & 0.36 & & & 0.184 & \\
\hline \multicolumn{9}{|l|}{$131-808 \mathrm{C}-$} \\
\hline $4 \mathrm{R}-1,130-145$ & 328.6 & 26 & 1335 & 0.36 & & 3.5 & 0.171 & 14880 \\
\hline $5 \mathrm{R}-\mathrm{CC}$ & 346.6 & & & & & & 0.154 & \\
\hline $10 \mathrm{R}-2,130-150$ & 388.1 & 41 & 1407 & 0.44 & & & & 22510 \\
\hline $11 \mathrm{R}-2,50-83$ & 396.8 & & & & & & 0.297 & \\
\hline $12 \mathrm{R}-1,130-150$ & 406 & 37 & 1341 & 0.43 & & & 0.274 & 21090 \\
\hline $13 R-2,135-150$ & 417 & 39 & 1334 & 0.50 & 44 & 2.9 & 0.281 & 23590 \\
\hline $14 \mathrm{R}-3,131-150$ & 428.4 & 38 & 1486 & 0.51 & & & 0.293 & 22560 \\
\hline $15 \mathrm{R}-1,130-150$ & 435.1 & 39 & 1383 & 0.53 & & & 0.244 & 21760 \\
\hline $15 \mathrm{R}-4,115-150$ & 439.5 & 33 & 1411 & 0.54 & & & & 21210 \\
\hline $16 \mathrm{R}-2,130-150$ & 446.9 & 42 & 1343 & 0.55 & & & 0.225 & 19210 \\
\hline $17 R-4,130-150$ & 458.6 & 43 & 1389 & 0.46 & & 3.1 & 0.218 & 19060 \\
\hline $18 \mathrm{R}-3,130-150$ & 466.8 & 40 & 1373 & 0.58 & & & 0.211 & 18640 \\
\hline $19 \mathrm{R}-2,127-150$ & 474.8 & 35 & 1448 & 0.58 & & & & 20460 \\
\hline $20 \mathrm{R}-4,132-150$ & 487.6 & 31 & 1458 & 0.50 & & & & 20030 \\
\hline $21 \mathrm{R}-1,120-144$ & 492.6 & 24 & 1442 & 0.44 & & 56.6 & 0.188 & 17410 \\
\hline $22 \mathrm{R}-3,130-160$ & 505.4 & 23 & 1402 & 0.63 & & & & 18610 \\
\hline $25 \mathrm{R}-2,125-150$ & 531.6 & & & & & 11.4 & & \\
\hline $29 \mathrm{R}-6,125-150$ & 577.5 & & & & & 12.1 & & \\
\hline $32 \mathrm{R}-3,125-150$ & 601.6 & 25 & 1336 & 1.02 & & & & 11260 \\
\hline $34 \mathrm{R}-2,125-150$ & 619.4 & 24 & 1347 & 0.77 & & & & 10790 \\
\hline $35 R-4,132-150$ & 632.1 & 35 & 1363 & 1.15 & & 42.4 & 0.083 & 10710 \\
\hline $36 \mathrm{R}-2,125-150$ & 638.7 & 22 & 1379 & 1.20 & & & & 10360 \\
\hline $41 \mathrm{R}-1,123-150$ & 685.1 & & & & & 20.5 & 0.147 & \\
\hline $42 \mathrm{R}-3,125-150$ & 697.8 & 22 & 1213 & 1.83 & & & & 14540 \\
\hline $43 R-5,0-25$ & 709.3 & 17 & 1205 & 1.27 & & & & 19160 \\
\hline $46 R-2,125-145$ & 734.4 & 18 & 1189 & 1.99 & 44 & 19.4 & & 10980 \\
\hline $48 \mathrm{R}-3,125-150$ & 755.6 & 17 & 1139 & 1.84 & & & & 13760 \\
\hline $49 \mathrm{R}-2,125-150$ & 763.7 & & & & & & 0.108 & \\
\hline $50 \mathrm{R}-5,125-150$ & 778 & & & & 43 & 13.9 & & \\
\hline $52 \mathrm{R}-5,120-150$ & 797 & & & & & 7.6 & 0.069 & \\
\hline $55 \mathrm{R}-2,120-150$ & 822 & 15 & 1100 & 1.83 & & & & \\
\hline $57 R-2,120-150$ & 841 & 15 & 1019 & 2.25 & & & & 21240 \\
\hline $59 \mathrm{R}-2,125-150$ & 860 & & & & 44 & & & \\
\hline $61 R-2,115-150$ & 878.8 & & & 2.05 & 39 & & & \\
\hline $64 \mathrm{R}-1,115-150$ & 906.9 & & 1192 & 2.19 & & 38.8 & 0.081 & \\
\hline $70 R-4,0-35$ & 968 & & & & 34 & & & \\
\hline $71 R-2,120-150$ & 976 & 22 & 1112 & 3.21 & & & & \\
\hline $71 \mathrm{R}-3,105-150$ & 977.4 & & & & & & 0.116 & \\
\hline $72 R-3,0-35$ & 986 & 19 & 1068 & 2.94 & & & & 29590 \\
\hline $73 R-5,115-150$ & 999.5 & 18 & 1079 & 3.11 & & 55.7 & 0.088 & \\
\hline $74 \mathrm{R}-2,72-114$ & 1004.5 & 19 & 1152 & 2.57 & & 53.1 & 0.036 & \\
\hline $77 \mathrm{R}-4,0-35$ & 1034 & & & & 28 & & & \\
\hline $78 R-2,115-150$ & 1042 & 19 & 1044 & 2.46 & & & & 17040 \\
\hline $84 \mathrm{R}-1,120-150$ & 1099.3 & 35 & 1008 & 1.79 & & & & \\
\hline $86 \mathrm{R}-2,115-150$ & 1110.8 & 24 & 958 & 2.18 & & 39.4 & 0.027 & 5060 \\
\hline $94 \mathrm{R}-1,0-35$ & 1185 & & & & 29 & & & \\
\hline
\end{tabular}

${ }^{\text {a Absorbance unit }}$ 

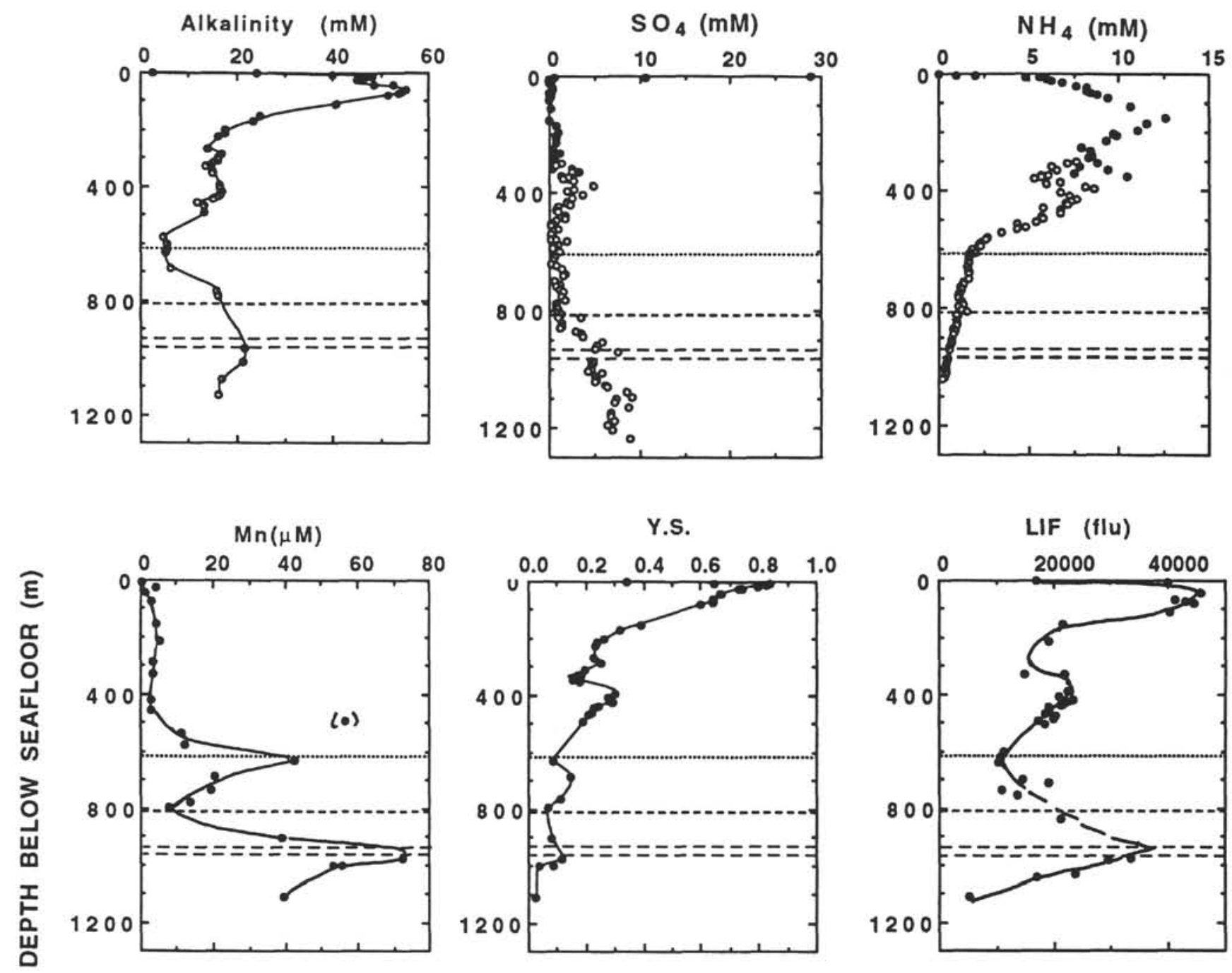

Y.S.
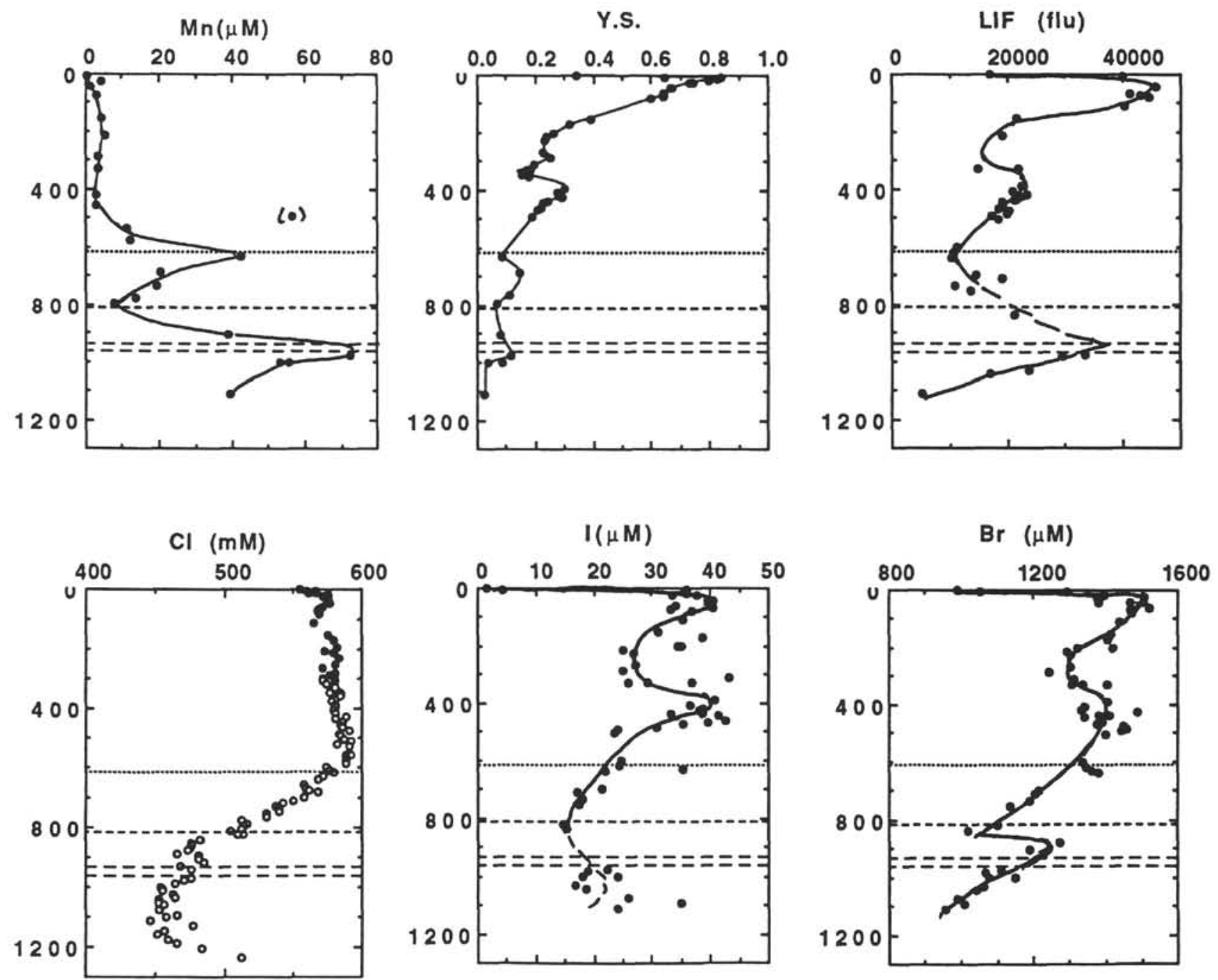

Figure 3. Concentration-depth profiles of alkalinity, sulfate, ammonium, manganese, yellow substance absorbance (YS), laser-induced fluorescence (LIF), chloride, iodide, and bromide in interstitial waters of Site 808 . 

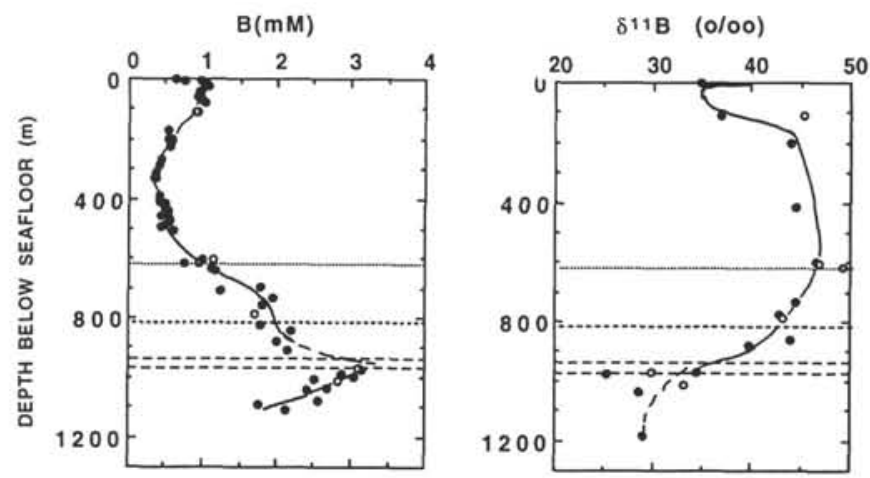

Figure 4. Boron and $\delta^{11} \mathrm{~B}$ in interstitial waters of Site 808.

the interstitial water profiles determined onboard ship, e.g., calcium, magnesium, potassium, lithium (Taira, Hill, Firth, et al., 1991; Gieskes et al., this volume).

For an understanding of these observations it is appropriate to represent the profiles of ammonium, magnesium, calcium, and boron over the depth interval of 300-600 mbsf (Fig. 8). All these profiles, with the exception of boron, show concentration reversals that are associated with the major fault which occurs near $365 \mathrm{mbsf}$, and they are related to a thrust of sediments from a depth of more than $100 \mathrm{~m}$ deeper in the section over the sediments at about $365 \mathrm{mbsf}$ (Taira, Hill, Firth, et al., 1991). In addition this fault zone is characterized by sediment folding, similar to that observed in the northern Barbados accretionary prism (Moore, Mascle, Taylor, et al., 1990). These processes, therefore, have led to the emplacement of sediments with lower dissolved ammonia and magnesium and higher dissolved calcium, above sediments with higher/lower concentrations. For boron no extremes are observed because of the relative constancy of the boron concentrations between 300 and 500 mbsf. In turn this leads to a non-steady state distribution of the parameters with depth. The faulting probably has occurred in the recent past and for these reasons vertical diffusive exchange has as yet not eradicated these concentration reversals. If thrusting occurred $<20 \mathrm{ka}$ ago, the diffusive path length (defined as (2Dt) $1 / 2$, with $\mathrm{D} \sim 2 \times 10^{-6} \mathrm{~cm}^{2} / \mathrm{s}$ ) would have been less than $15 \mathrm{~m}$. Under these circumstances there would not have been sufficient time for diffusive exchange to smooth out any anomalies. Therefore, the anomalies in the concentration depth profiles of iodide, bromide, YS, and LIF (Fig. 3) can also be understood best in terms of the above described faulting process. The scatter in the data for iodide and bromide does not allow the precise delineation of the concentration reversals. The faulting may have occurred much more recently than $20 \mathrm{ka}$ ago, which is also evident from the lack of establishment of a porosity gradient over this depth range (Warner Bruckmann, pers. comm., 1991; see also this volume). Because of this constancy in porosity essentially no significant water expulsion has been involved in this section of the hole associated with the fault, thus allowing the preservation of the concentration anomalies.

\section{Shikoku Basin Deposits}

For many of the interstitial water components distinct changes occur below the boundary between the trench fill turbidites and the Shikoku Basin deposits (Fig. 1) at about 620 mbsf. This is particularly the case for alkalinity, boron, sulfate, LIF, chloride, bromide, and iodide(?), as demonstrated in the profiles of Figures 3 and 4. In particular boron, LIF, manganese, and bromide show maximum concentrations in or near the zone of décollement.

The most noticeable feature of the shipboard pore fluid data (Taira, Hill, Firth, et al., 1991) was the well-defined decrease in dissolved chloride below $\sim 620 \mathrm{mbsf}$, with a minimum at $\sim 1100 \mathrm{mbsf}$, i.e., well below the zone of décollement. Such chloride decreases have been observed previously in sediments of accretionary prisms, e.g., Sites 671-676 of the Barbados accretionary prism transect, ODP Leg 110 (Gieskes et al., 1990a, b; Vrolijk et al., 1991; Blanc et al., 1991) and also off the coast of Peru (Elderfield et al., 1990; Kastner et al., 1991). In those instances the low chloride concentrations, usually associated with fault zones, were considered to reflect expulsion of fluids from the interior of the accretionary prism or from subducting sediments. Possible mechanisms causing the low chloride concentrations have been discussed by Gieskes et al. (1990a, b), Kastner et al. (1990), and Blanc et al. (1991). If the principal input of this low chloride fluid is indeed along the décollement or through the underlying sediments, and if this event occurred not much longer ago than the age of the décollement at this site, i.e., about $500 \mathrm{ka}$ ago (the age of the initiation of the trench deposition), then it will be necessary to consider a model in which an initial large pulse of low chloride fluid must have occurred, not only in a lateral but also in a vertical direction, at least up to a depth of $\sim 820 \mathrm{mbsf}$. Only under these circumstances would there have been sufficient time to establish a diffusive gradient between 625 and 820 mbsf (Taira, Hill, Firth, et al., 1991). This problem is discussed in greater detail elsewhere in this volume by Kastner et al.

The profiles of boron, bromide, manganese, and LIF, however, do not suggest a strong resemblance to that of dissolved chloride. This suggests an input, presumably in the vicinity of the décollement, of a fluid enriched in these components, perhaps as recently as $\sim 200 \mathrm{ka}$ ago. The latter time limit would allow diffusive gradients to develop over a distance of about $110 \mathrm{~m}$, assuming a diffusion coefficient of $10^{-5} \mathrm{~cm}^{2} / \mathrm{s}$. The data do not allow us to estimate how often advective inputs do occur along the zone of décollement, or indeed whether it is continuous or of an intermittent nature. In view of the low porosities of the section we assume that the input is of an episodic nature. The various observed anomalies in the zone of décollement are not completely symmetrical, in part as a result of potential reactions affecting some of the components, e.g., potential production of boron and LIF, in addition to the advective input of fluids along the zone of décollement. Also diffusive exchange will be different for the various components. The data base does not allow an evaluation of this problem.

The occurrence of maxima in bromide, iodide(?), and LIF suggests that a component associated with the alteration of organic carbon is associated with the fluid inputs along the décollement. Of some interest is the lack of an increase in YS, which leads to a quite different correlation between YS and LIF in the deeper section of the site (Fig. 7). Preliminary work on the dissolved fluorescent component of the dissolved organic matter (DOM), based on RP-HPLC/LIF analyses, suggests a major compositional change of the DOM at the décollement, when compared to the upper sediments (Chen, 1992). A graphical summary of this information is presented in Figure 5. It is evident that the sediment column can be divided into three zones: the upper $100 \mathrm{mbsf}$, with polar fluorescent compounds dominant (retention times $\sim 4.2$ and $4.9 \mathrm{~min}$ ), somewhat similar to seawater organic compounds; the middle zone $\sim 100-650 \mathrm{mbsf}$, with a gradual shift to compounds with increasing hydrophobicity (longer retention times), possibly resulting from the loss of functional groups with increasing age or temperature, as well as from some possible upward diffusion of hydrophobic compounds from the lowermost zone; and the zone below $\sim 750 \mathrm{mbsf}$ and especially the zone around the décollement, which is characterized by the disappearance of the polar molecules and a predominance of hydrophobic molecules with a retention time of $\sim 5.3-5.5$ minutes, similar to a dominant peak found in Guaymas Basin pore waters, which contain thermally generated hydrocarbons (Chen, 1992).

It is, therefore, feasible that fluids from further in the accretionary complex stemming from an organic carbon-rich zone, but also characterized by higher temperatures, penetrate, or have penetrated, into the sediments along the zone of décollement. These fluids also are enriched in boron as a result of the release of this component at higher temperatures. Typically lower $\delta^{11} \mathrm{~B}$ values are associated with the 
Peak Area

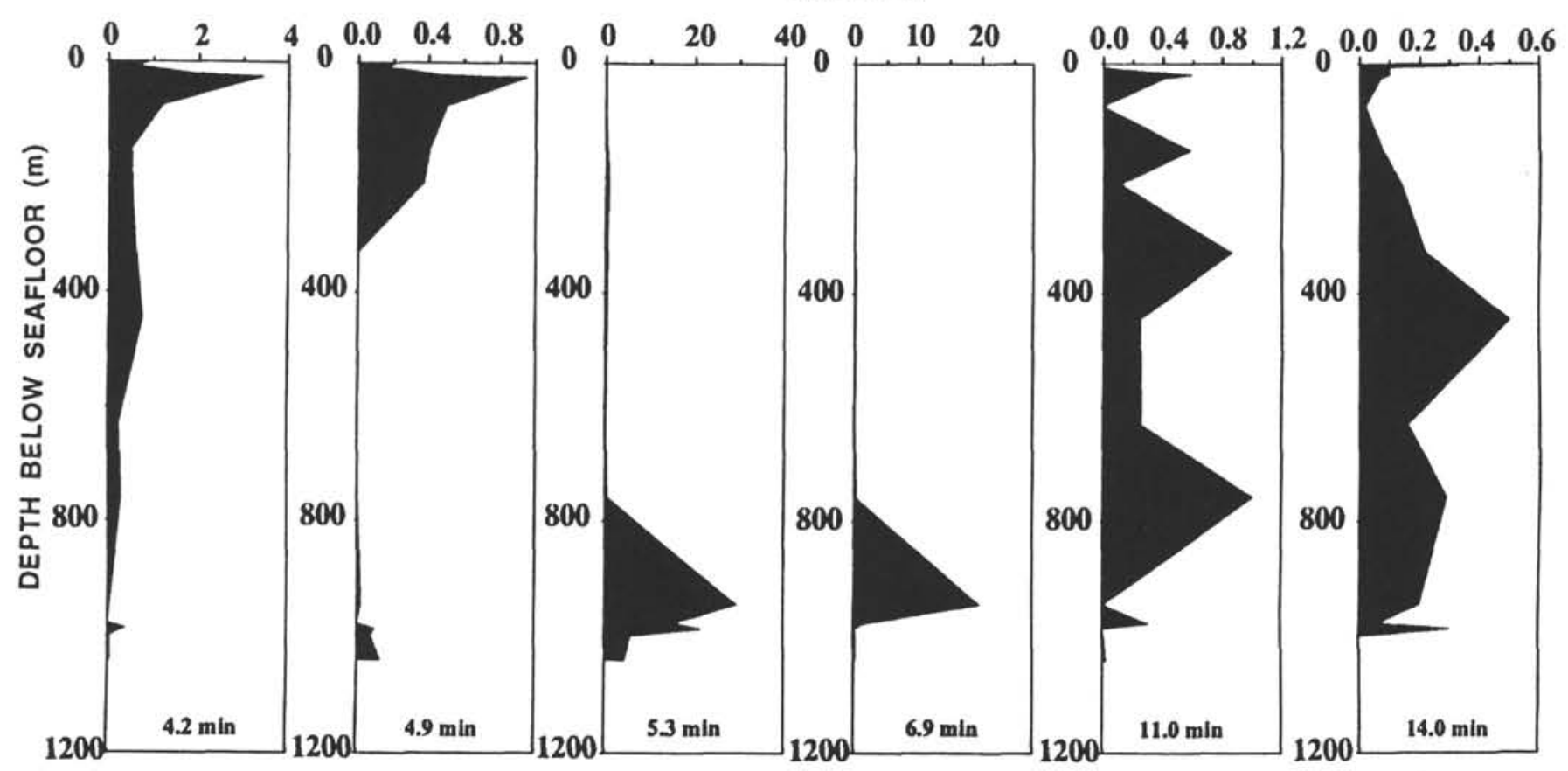

Figure 5. Peak area-depth distribution of compounds separated by RP-HPLC with LIF detection, Site 808 .

elevated boron concentrations (Fig. 4). In the pore fluids of Sites 671 and 672 of Leg 110 similar enrichments in boron have been observed by us in the vicinity of the sandstone layers that act as major conduits of fluid expulsion (Vrolijk et al., 1991).

Of some interest is the profile of dissolved manganese. Several layers of highly enriched solid manganese concentrations have been identified around the depth of $\sim 1100$ mbsf (Underwood et al., this volume). However, if this manganese were to be present in the form of manganese oxides, then high dissolved manganese concentrations would be expected in these depth horizons as a result of manganese oxide reduction. This has not been observed.

\section{SUMMARY AND CONCLUSIONS}

The data presented in this paper concern themselves mostly with interstitial water components that are closely related to diagenetic processes involving organic matter. The data, however, are relevant to processes occurring in Site 808, which is located on the landward side of the Nankai Trough. The most relevant observations are summarized below:

1. In the upper rapidly deposited sediments of the trench fill turbidites, the decomposition of organic carbon has led to observed large increases in alkalinity, ammonium, bromide, iodide, YS absorbance, and LIF. The latter two components are proportional to the dissolved organic carbon. Concentrations of dissolved boron suggest a mobilization of boron (presumably adsorbed boron) into the pore fluids as a result of chemi-sorptive interaction with dissolved marine humic matter. If this is so, then the increase in dissolved boron would require a boron to organic carbon ratio of about $5 \times 10^{-2}$ on a mole to mole basis. Release of adsorbed boron is evident from the lowering of the $\delta^{11} \mathrm{~B}$, as adsorbed boron has a $\delta^{11} \mathrm{~B}$ of about $15 \%$.

2. Several of the dissolved constituents indicate concentration reversals centered around the thrust fault at $~ 365 \mathrm{mbsf}$ in Hole $808 \mathrm{C}$. This reversal is the result of overthrusting of a sediment section from $\sim 100$ m deeper in the sediment column, which is also associated with considerable folding. Because of almost constant porosities between
300 and 500 mbsf little or no expulsion is associated with the thrust-faulting processes. This causes the concentration depth profiles to be subject only to diffusive smoothing. Lack of such smoothing suggest that the faulting has occurred less than $20 \mathrm{ka}$ ago.

3. Maxima in bromide, iodide(?), boron, manganese, and LIF, centered in the zone of décollement suggest that an input of fluid can occur along the décollement zone, at least in an episodic manner. The enrichment in bromide, iodide, and especially of organic matter of an apparent thermal origin, suggests advection of fluids along the décollement zone, which are enriched in constituents that have their origins in part from the decomposition of organic matter. A reasonable source of these fluids would be fluids from further in the accretionary prism, presumably from an organic-carbon rich section.

4. Boron concentrations also show a maximum at or near the zone of décollement, with $\delta^{11} \mathrm{~B}$ values decreasing to $28 \pm 2 \%$, i.e., values substantially lower than those of modern seawater $\left(\delta^{11} \mathrm{~B} \sim 39.5 \%\right.$ ). Similar observations have been made in the northern Barbados accretionary transect, and this suggests that boron is released at depth, in the form of adsorbed boron or perhaps also as fixed boron.

\section{ACKNOWLEDGMENTS}

We thank our shipboard colleagues for their cooperation and we also thank our reviewers Drs. Hans Brumsack and William Leeman for their reviews of an earlier version of this paper. Peter Vrolijk is gratefully acknowledged for his editorial patience and input. This work was supported by the United States Science Committee (JOIUSSAC) to J.M. Gieskes as well as by grants NSF-EAR 89-04573 (A. Spivack) and ONR N00014-89-J-1422 (R. Chen/J. Bada).

\section{REFERENCES}

Blanc, G., Boulegue, J., and Gieskes, J.M., 1991. Chemical evidence for advection of interstitial fluid in the sedimentary series of the Barbados accretionary complex (Leg 110). Oceanol. Acta, 14:33-49.

Boulegue, J., liyama, J.T., Charlou, J.L., and Jedwab, J., 1987. Nankai Trough, Japan Trench, and Kuril Trench: geochemistry of fluid samples by submersible "Nautile." Earth Planet. Sci. Lett., 83:362-375. 
Bray, C.J., and Karig, D.E., 1985. Porosity of sediments in accretionary prisms and some implications for dewatering processes. J. Geophys. Res., 90:768-778.

Brumsack, H.J., and Gieskes, J.M., 1983. Interstitial water trace-metal chemistry of laminated sediments from the Gulf of California, Mexico. Mar Chem., 14:89-106.

Chen, R.F., 1992. Fluorescence of dissolved organic matter in the marine environment. [Ph.D. dissert.]. Univ. of California, San Diego.

Chen, R.F., and Bada, J.L., 1990. A laser-based fluorometry system for investigations of seawater and pore water fluorescence. Mar. Chem. 31:219-230.

Cloos, M., 1984. Landward dipping reflectors in accretionary wedges: active dewatering conduits? Geology, 12:519-522.

Elderfield, H., Kastner, M., and Martin, J.B., 1990. Composition and sources of fluids in sediments of the Peru subduction zone. J. Geophys. Res., 95:8819-8828.

Gieskes, J.M., 1983. The chemistry of interstitial waters of deep sea sediments: interpretation of Deep Sea Drilling data. Chem. Oceanogr., 8:221-269.

Gieskes, J.M., Gamo, T., and Brumsack, H., 1991. Chemical methods for interstitial water analysis aboard JOIDES Resolution. ODP Tech. Note, 15:60.

Gieskes, J.M., Blanc, G., Vrolijk, P., Elderfield, H., and Barnes, R., 1990. Interstitial water chemistry - major constituents. In Moore, J.C., Mascle, A., et al., Proc. ODP, Sci. Results, 110: College Station, TX (Ocean Drilling Program), 155-177.

Gieskes, J.M., Vrolijk, P., and Blanc, G., 1990. Hydrogeochemistry of the Northem Barbados Accretionary Complex Transect: Ocean Drilling Program Leg 110. J. Geophys. Res., 95:8809-8818.

Han, M.W., and Suess, E., 1989. Subduction-induced pore fluid venting and the formation of authigenic carbonates along the Oregon/Washington continental margin: implications for the global Ca cycle. Palaeogeogr. Palaeoclimatol., Palaeoecol., 71:97-118.

Harrison, W.E., Hesse, R., and Gieskes, J.M., 1982. Relationship between sedimentary facies and interstitial water chemistry of slope, trench, and Cocos-Plate sites from the Mid-America trench transect, active margin off Guatamala. In Aubouin, J., von Huene, R., et al., Init. Repts. DSDP, 67: Washington (U.S. Govt. Printing Office), 603-616.

Hesse, R., Lebel, J., and Gieskes, J.M., 1985. Interstitial water chemistry of gas-hydrate-bearing sections on the Middle America Trench slope, In von Huene, J.R., Aubouin, J., et al., Init. Repts. DSDP, 84: Washington (U.S. Govt. Printing Office), 727-737.

Kastner, M., Elderfield, H., and Martin, J., 1990. Diagenesis and interstitial water chemistry at the Peruvian margin-major constituents and strontium isotopes. In Suess, E., von Huene, R., et al., Proc. ODP, Sci. Results, 112 College Station, TX (Ocean Drilling Program), 413-440.

1991. Fluids in convergent margins: what do we know about their composition, origin, role in diagenesis, and importance for oceanic geochemical fluxes. Philos. Trans. R. Soc. London A, 335:243-259.
Kennedy, H.A., and Elderfield, H., 1987a. Iodine diagenesis in pelagic deep sea sediments. Geochim. Cosmochim. Acta, 51:2489-2504.

,$- 1987 \mathrm{~b}$. Iodine diagenesis in non-pelagic deep sea sediments. Geochim. Cosmochim. Acta, 51:2505-2514.

Krom, M.D., and Sholkovitz, E.R., 1977. Nature and reactions of dissolved organic matter in the interstitial waters of marine sediments. Geochim. Cosmochim. Acta, 41:1565-1573.

Kulm, L.D., Suess, E., et al., 1986. Oregon subduction zone: venting, fauna, and carbonates. Science, 231:5661-566.

LePichon, X., Henry, P., and Lallement, S., 1990. Water flow in the Barbados accretionary complex. J. Geophys. Res., 95:8945-8967.

Mascle, A., Moore, J.C., et al., 1988. Proc. ODP, Init. Repts., 110: College Station, TX (Ocean Drilling Program).

Michaelis, W., Mycke, B., Vogt, J., Schuetze, G., and Degens, E., 1982. Organic geochemsitry of interstitial waters, Sites 474 and 479, Leg 64. In Curray, J.R., Moore, D.G., et al., Init. Repts. DSDP, 64: Washington (U.S Govt. Printing Office), 933-937.

Moore, J.C., Mascle, A., et al., 1988. Tectonics and hydrogeology of the northern Barbados Ridge: results from Ocean Drilling Program Leg 110. Geol. Soc. Am. Bull., 100:1578-1593.

Moore, J.C., Mascle, A., et al., 1990. Proc. ODP, Sci. Results, 110: College Station, TX (Ocean Drilling Program).

Shipboard Scientific Party, 1991. Site 808. In Taira, A., Hill, I., Firth, J.V., et al., Proc. ODP, Init. Repts., 131: College Station, TX (Ocean Drilling Program).

Spivack, A.J., and Edmond, J.M., 1987. Boron isotope exchange between seawater and the oceanic crust. Geochim. Cosmochim. Acta, 51:1033-1043.

Vrolijk, P.J., Chambers, S.R., Gieskes, J.M., and O'Neil, J.R., 1990. Stable isotope ratios of interstitial fluids from the Northern Barbados Accretionary Prism, ODP Leg 110. In Moore, J.C., Mascle, A., et al., Proc. ODP, Sci. Results, 110: College Station, TX (Ocean Drilling Program), 189-205.

Vrolijk, P.J., Fisher, A., and Gieskes, J.M., 1991. Geochemical and geothermal evidence for fluid migration in the Barbados accretionary prism (ODP Leg 110). Geophys. Res. Lett., 5:947-950.

Wang, Y.-C., Gieskes, J.M., and Musoke, L., 1988. Halide geochemistry of interstitial waters of Deep Sea Drilling cores-some observations and problems. Eos, 69:1263.

White, S., 1975. Interstitial water studies, Leg 31. In Karig, D.E., Ingle, J.C., Jr., et al., Init. Repts. DSDP, 31: Washington (U.S. Govt. Printing Office), 639-653.

Date of initial receipt: 26 September 1991

Date of acceptance: 19 August 1992

Ms 131SR-116 


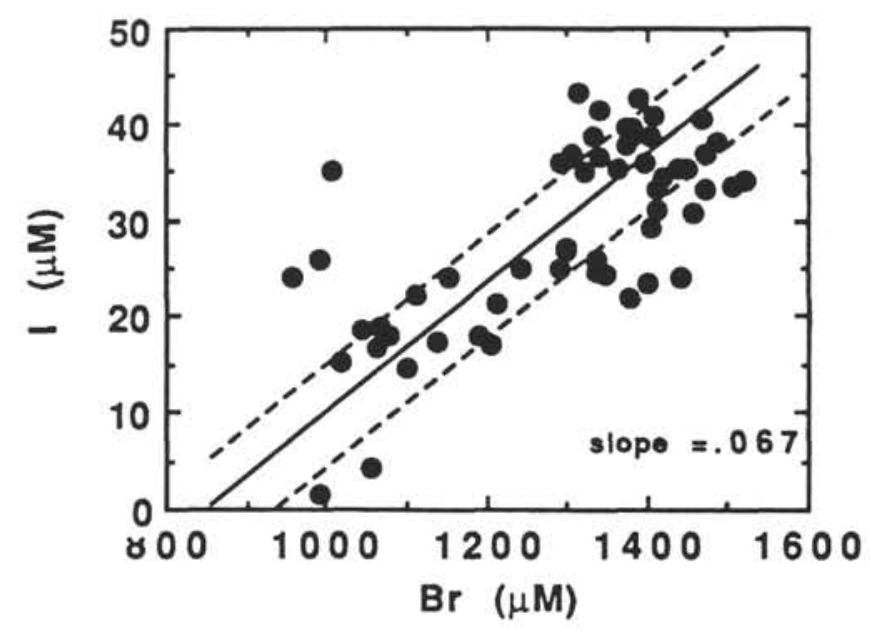

Figure 6. Correlation plot of iodide and bromide in interstitial waters, Site 808. Scatter principally due to small size samples for iodide determination.

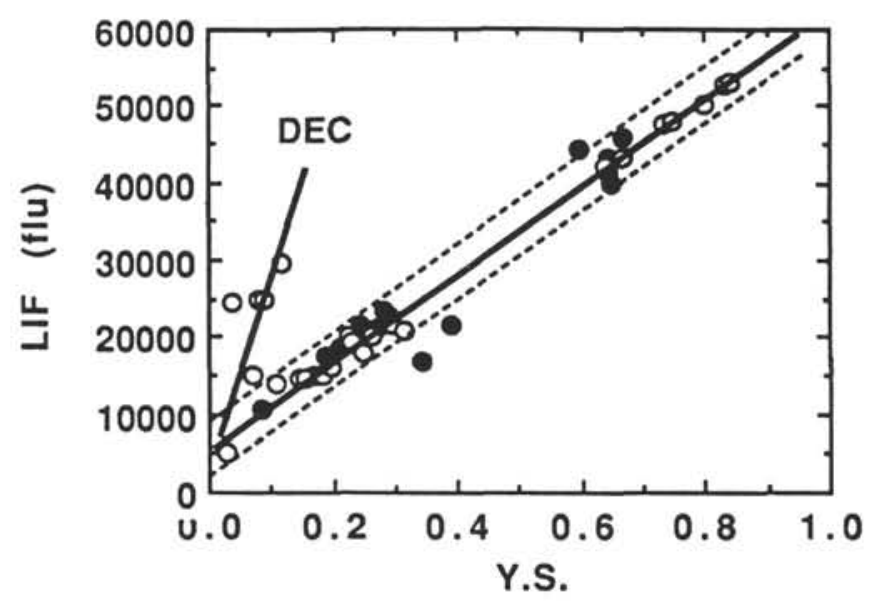

Figure 7. Correlation plot of YS and LIF, Site 808. Note the different correlation in the zone of décollement (DEC).

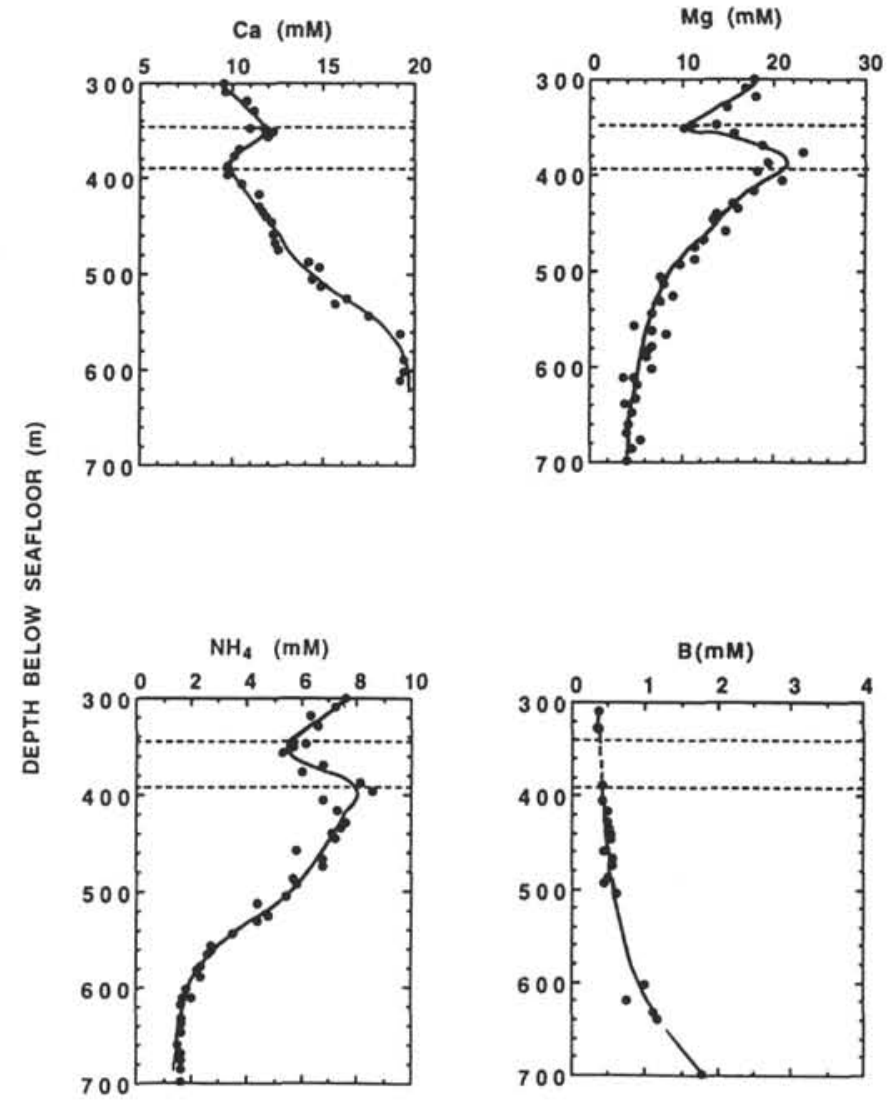

Figure 8. Concentration-depth profiles of dissolved calcium, magnesium, ammonium, and boron in Hole $808 \mathrm{C}$, from 300 to $700 \mathrm{mbsf}$. Note concentration reversals in $\mathrm{Ca}, \mathrm{Mg}, \mathrm{NH}_{4}$ associated with the thrust fault centered around $\sim 365$ mbsf. 